\title{
Study on the Influence and Countermeasures of MOOC on Higher Education in China
}

\author{
Zhu Peiping ${ }^{1}$; Wang Qionghui ${ }^{1}$ \\ Department of physical science and technology, Kunming \\ University, Kunming, China, 650214 \\ 3267002772@qq.com
}

\begin{abstract}
This paper summarizes the present situation of MOOC and higher education in China by literature research, questionnaire survey, empirical research and other methods, introduces the characteristics of MOOC, the problems of higher education in China and finds the impacts of MOOC on higher education in China. Combing with the reality of the times and the development of technology, based on the characteristics of the MOOC analyzes and discusses the countermeasures of further development of China's higher education in the era of MOOC.
\end{abstract}

Keywords-MOOC; higher education; influence; countermeasure

\section{INTRODUCTION}

The MOOC has its own unique advantages in the rapid development of the world. It is a new teaching mode and "student-centered" teaching concept of the impact of higher education in China. MOOC effects higher education is not only to enhance the technical education reform, teaching means, but also contains teachers' teaching philosophy, teaching methods and students' learning style transformation. MOOC effects the education management and the education system in China. Through literature research, it is found that the research on the impact of the MOOC on the higher education and the countermeasures to develop the higher education in China are not many. Therefore, this paper discusses the problem.

\section{THE MEANING AND DEVELOPMENT STATUS OF}

\section{MOOC}

Massive Open Online Course (MOOC), the learners can participate in learning, completing the homework, evaluating progress of the study, taking part in the examination, and the exchange of students. MOOC is analyze students' personality traits, learning behavior, learning process through data. According to the students' learning rules to design teaching. Teachers can carry out targeted teaching. It would help to improve student learning efficiency and quality.

In 2001, Massachusetts Institute of Technology opened a

The research results of Kunming university Fund for Scientific Research

\author{
Dong $\mathrm{Yao}^{2}$ \\ Department of physical science and technology, Kunming \\ University, Kunming, China, 650214 \\ 57056253@qq.com
}

free Internet course. In 2012, Coursera`s free courses online. In the same year, the Harvard University and the Massachusetts Institute of Technology jointly implemented the edX online teaching plan. The number of people to participate in the study of nearly 400 thousand. The number of MOOC institutions in the United States is growing exponentially [1]. Many developed countries have joined the MOOC.

2013, China formally introduced MOOC.MOOC's development is very rapid. China has built a number of MOOC platforms, such as the tree of knowledge, the netease open class, sina open class, tencent class, love class network. Some famous universities, such as Peking University, Tsinghua University, University of Hong Kong and Shanghai Jiao Tong University, Hong Kong University Science \& Technology, were joined in the construction of the MOOC. In 2014, in the promotion of the ministry of education, "love class network" set up "China University MOOC". It offers online courses for the universities. It used to push MOOC to a new height. Up to now, there are 81 schools in the MOOC of China's universities.

\section{ADVANTAGES OF MOOC}

With the development of the network, the transmission speed of the network has been greatly improved, which provides a good hardware condition for the development of network learning. As an online learning method, MOOC has unique characteristics. Such as large scale, Openness, interactivity, personalized, "learning oriented" teaching mode and micro video teaching content and teaching organization form, etc. MOOC has the advantages of the following points.

First, MOOC provides high quality and abundant teaching resources. MOOC course by the famous masters of the production. MOOC has high teaching quality and rich teaching resources. It is a good solution to the lack of excellent teachers and quality curriculum resources in some universities.

Second, MOOC is in line with the characteristics of contemporary students` learning. For the teaching content of high quality, short and pithy. Students living in the era of information technology, students can use fragmentation time choose the courses that they are interested through the MOOC, Students also can participate of communication between

topics (ID: XJZD1601) for 2016 years. 
teachers and students. It is meet the needs of the students' learning characteristics and autonomous learning [2].

Third, MOOC promote the common development of between teachers and students. Teachers and students can use high quality courses to learn and improve themselves. MOOC has strong interactivity. In the online learning process, students have questions can be made at any time, the teacher can answer in a timely manner.

\section{THE INFLUENCE OF MOOC ON THE HIGHER}

\section{EDUCATION IN CHINA}

The rapid development of MOOC, with its unique advantages into the student's learning. MOOC has a serious impact.

\section{A. The influence of MOOC on teachers}

First, MOOC changes teachers' role and teaching ideas.

Teachers have "preaching, tuition, FAQ", and "take the teacher as the main body" philosophy in higher education. Students initiative is not fully play. The education teaching idea of MOOC reflects the openness, the large scale and the individuality, and emphasizes that the teaching should take the student as the main body. This requests the teacher to change the teaching idea as soon as possible, to change "take the teacher as the main body" to "take the student as the main body".

Second, MOOC changes the teaching methods of higher education.

Higher education is the teaching mode of "teaching as the main", and the students accept the knowledge passively. MOOC will be a large number of complex teaching content fragmentation, production into a micro video. Before class, in class and after class, students are arranged different learning tasks. Teachers let the students through online ahead of self-completion of the low level of awareness, understanding, memory and learning tasks, interaction, sharing of link analysis, exploratory learning content. The way of teaching is fully mobilize students` learning initiative and arouse the students' creative potential.

Third, MOOC improves the teacher's teaching ability and professional level.

MOOC let teachers learn quality courses through the platform MOOC. Teachers can comparison and reference knowledge and wisdom to strengthen their own teaching experience, to enhance the teaching ability and professional level, and maximize the optimization of teaching effect [3].

Fourth, MOOC provides more abundant teaching resources for teachers.

In the classroom, teachers put the teaching materials and courseware as the center. Dull teaching method can not mobilize the enthusiasm of the students. The dynamic teaching content include video and animation can fully arouse the students' learning interest and enthusiasm.

\section{B. The influence of MOOC on students}

First, personalized learning becomes possible.

Learners can choose their own way of learning through MOOC, according to the structure of knowledge, the level of acceptance, the interests and hobbies. Students choose personalized learning content and free learning schedule. In the process of learning, students complete the task of learning, and to communicate with students and teachers online. It cultivate the ability to communicate with others. The way of learning has improved the autonomy and enthusiasm of the students.

Second, MOOC broadens the knowledge of learners.

MOOC has high-quality teaching resources. Learners can choice quality courses according to their own needs or interests. Learners get some knowledge and skills. It is meet the learning needs of students with diversified and personalized.

\section{The influence of MOOC on the educational management of universities}

First, MOOC improves the efficiency and quality of administrative management.

The administrative power of higher education is too concentrated, and some unreasonable administrative work system and evaluation system have bound the teachers' creative thinking, which has reduced the enthusiasm of teachers' self-teaching. The administrative management of the MOOC provides services for the teaching of teachers, the important standards of evaluate for teachers is the number of students` elective. Evaluation system is open and transparent. These can provide reference for the education management of higher education.

Second, MOOC improves the efficiency and quality of teaching management.

Due to the large number of students, teaching management can not grasp the characteristics of students in a timely manner. Management efficiency and quality is low. MOOC can analysis of students' personality characteristics, learning methods, learning process through big data comprehensive, to targeted teaching management, in order to improve the efficiency and quality of teaching management. In addition, MOOC help teachers find their own teaching problems through collection students opinions of teachers. It helps to improve the teaching ability of teachers, so as to realize the optimization of teaching.

\section{The influence of MOOC on the higher education system.}

First, MOOC can realize the sharing of higher quality of higher education resources.

MOOC can solve the problem of balanced allocation of educational resources in higher education, and promote educational equity. In the information age, MOOC broke the University's wall, the opening and networking of MOOC can spread the high quality courses to a wider range of people. Learners can have the opportunity to choose high-quality educational resources. MOOC provide free access to the learning experience and quality of teaching resources for the lack of educational resources in the region. It is achieve the sharing of high-quality resources of higher education. 
Second, MOOC can promote the reform of higher education system.

MOOC can make the high quality curriculum resources to be shared. It promotes the fairness of education. MOOC's reform of higher education affect the education ecosystem. It will also affect the education management of universities, and promote the reform of education system [4]. More and more universities join MOOC. The exchange and competition of talents in universities will be more frequent and intense. This will collapse forced the universities to accelerate the pace of reform of education system and teaching system.

\section{THE DEVELOPMENT OF HIGHER EDUCATION IN THE ERA OF MOOC}

The development of MOOC of our country's traditional higher education has cause a great on china's higher education. China's higher education in the "MOOC trend", the teachers, students, education management and education system must make rapid reaction and an appropriate substantive change, adapt teaching and learning under the new situation, In order to improve the quality of education and better sustainable development of China's higher education.

\section{A. In the part of teachers}

First, teaching should highlight the main position of the students.

In order to improve the teaching quality, teachers must change the role of teaching. From teaching to the student, guide, changing the role of the cooperation. From the teaching as the center to the study as the center of the transformation. Teachers should encourage students to develop their interest in teaching, highlight the dominant position of students. Teachers should encourage students to play their initiative and creativity.

Second, enhance the teaching ability and professional level of teachers.

University teachers should establish the concept of lifelong learning. Teachers should supple and improve the comprehensive knowledge and strength practice, and improve their professional level. In order to meet the needs of students to seek knowledge. Teachers should improve teaching ability and use teaching experience and professional knowledge to design teaching content.

Third, higher education and MOOC should be integrated with each other

The advantages of the MOOC and higher education can be combined with each other. Combination online and offline "mixed teaching model" can be realized "students as the main body" of the flipped classroom. This will not only play the role of teacher motivation, guidance, inspiration, but also stimulate the students' learning initiative and enthusiasm, so as to improve teachers` teaching quality and learning quality.

\section{B. In the part of students}

First, school should cultivate students' autonomous learning ability.
In the era of knowledge economy the comprehensive quality. Society put forward higher requirements to college students. Students improve their comprehensive quality only through continuous learning. Learning has become important means to realize the individual value and improve the quality of life. Learning will be accompanied by a lifetime. Therefore, Universities should focus on the cultivation of students' autonomous learning ability.

Second, students should cultivate the habit of autonomous learning.

For the students, in order to achieve personal all-round development and enhance the overall quality, students must develop science and health, autonomous learning habits and learning should maintain a high degree of enthusiasm for learning and initiative. Students should learn to use social science, computer science, psychology and other disciplines of knowledge to analyze and solve problems, to lay a solid foundation for their future career development [5].

\section{In the part of educational management}

First, Universities should establish a reasonable evaluation system.

The education management of universities can realize high efficiency and quality management with the advanced management idea of MOOC. Schools should attach importance to the training and the introduction of teachers. The administrative work should take the teaching as the center. It should provide convenience service for teachers and formulate reasonable working system and evaluation system. This will help to stimulating teachers ' creative thinking and mobilize the enthusiasm of teachers and improve teaching efficiency and quality.

Second, Universities should reform the teaching management system.

Universities should allow students to cross major, cross college, cross school elective courses of their favorite. Universities should establish mutual recognition of credits system and realize the sharing of high-quality curriculum in universities. In order to solve the problem the interest of the universities. Universities should open teaching equipment, allowing students to be based on their own needs across the professional, interdisciplinary, cross school use educational resources. This will improve the quality of higher education and the quality of students' training [6].

\section{In the part of educational system}

First, higher education should improve the development mechanism of teachers' teaching ability.

Universities should improve the development mechanism of teachers' teaching ability, promote the institutionalization of teacher training, quality evaluation, enable to participate in social practice regularly, and constantly improve the teaching ability of teachers.

Second, higher education should realize the sharing of high quality educational resources. 
Educational management departments should vigorously the construction and open service platform of educational resources, and promote the popularity and sharing of high-quality educational resources. Education management department should provide rich and high quality education resources to students. In order to improve the quality of education and promote the fairness of education.

Third, higher education should accelerate the reform of course system and course content.

Universities should develop a flexible meet the learning needs course of students of diversified and personalized. Universities should set up professional courses in line with the needs of students in employment. Every School should build professional courses and trying to do their own characteristics.

\section{CONCLUSION}

MOOC has a great influence on the educational idea, teaching mode and developing direction of higher education. Which can effectively promote the higher education is diversified and personalized direction to adapt to the development of 21 st century. MOOC provide reference to improve the quality of higher education. The students who is made by higher education to cultivate the all-round development that is fit for the requirements of the society.

\section{REFERENCES}

[1] Wang Qiong. The Evidences of MOOCs' Impact on Higher Education[J].Open Education Research.No.3 Jun.2016:37-42

[2] Wang Lili. The present situation and localization strategy of overseas university's MOOC [J].Overseas Chinese education.No.1 2016:138

[3] Sun Yingjun. Discussion about teaching model in colleges and universities in the background of MOOCs [J].Journal of university of shanghai for science and technology, 2015, 37(3):260-264.

[4] Chen Qiang. The influence of "Mu class" and the coping strategies of College Teachers [J].Journal of Longyan University, 2014, 32(6):83-87.

[5] Lv Zhonghua. The influence and Enlightenment of MOOC to the education in Colleges and Universities [J].Journal of Changchun university of technology (higher education study edition), 2014, 35(2):25-26.

[6] Wu weizhong, Guan Xiaohui, Qu Zhaoyang. The reflection on the teaching reform of MOOC wave triggered [J].Journal of northeast normal university (philosophy and social sciences), 2015, 274(2):190-194.. 